\title{
Helicopter Money: Central Banks as Spenders of Last Resort?
}

\author{
Comments on the book Between Debt and the Devil: \\ Money, Credit, and Fixing Global Finance by Adair Turner*
}

Hans-Jörg Naumer

With the four big central banks - the Bank of Japan, the US Federal Reserve (the Fed), the Bank of England, and the European Central Bank (in chronological order) - either rescuing or having rescued the financial markets from crisis mode while stimulating the economy by means of quantitative easing (QE), Adair Turner has started a public debate stretching beyond the realm of academic discussion, which has gone practically unnoticed: economic stimulus programs financed by helicopter money to permanently banish the threat of deflation. With government budgets having reached their limits, central banks would become spenders of last resort.

Turner's most recent book Between Debt and the Devil - Money, Credit, and Fixing Global Finance deals with the question regarding whether central banks should receive a mandate to finance economic stimulus programs by printing money directly (helicopter money) to avoid the looming threat of deflation (Turner 2015). Government bond purchases by central banks in the context of QE have hitherto served to increase liquidity in the banking system, thereby opening the credit channel, which, in turn, was intended to act as the starting

\footnotetext{
* Turner, Adair (2016), Between Debt and the Devil: Money, Credit, and Fixing Global Finance, Princeton University Press, Princeton, NJ, 302 pages.
}

point for rising capital investment. Further, QE has, so far, only indirectly helped to finance national budgets by reducing the interest burden on public debt. In the case of this new monetary policy instrument, central banks would finance "fiscal" stimulus packages with the aid of the printing press directly (Naumer 2015).

Turner attempts to explain the reasons for the financial market crises of recent decades by focusing on their origins. Moreover, he offers solutions and preventive methods to avoid such crises permanently, and, at the same time, to overcome anemic global growth. Many of his analyses are well known, but the explanations are in need of some elaboration. Certainly, Turner is right that the crises - starting with the bubble that burst at the beginning of the 1990s in Japan - were crises of excessive growth in credit, accompanied by bad investments and lax lending policies of banks, which were then amplified by new forms of finance, such as bundling of different-quality loans into subprime securities. This is just one side of the coin, however. What Turner's observations almost ignore is monetary policy, which - starting with the Bank of Japan - flooded the markets with excessive liquidity to combat crises and was continued or better, intensified - by the Fed and, later, by the European Central Bank with their policies of QE. Turner also 
does not mention the Clinton-era house-building program. This program ultimately led to the house price and financial crisis in the US by encouraging cheap mortgages in connection with new forms of finance and climaxed in the collapse of Lehman Brothers. He explains the euro area debt crisis by pointing to both lack of a central fiscal authority and high interest rates, which limited the possibilities for governments to accumulate budget deficits. There is no word about how the convergence of bond yields and, thus, of funding costs in the entire currency area toward the German level during the early days of the single currency finally led to the real estate crisis in Spain, while making it easier for countries in the euro periphery to issue debt at lower rates of interest. However, anyone who wants to find solutions to the causes of the crises must look not only at the transmission channels by which capital was misallocated but at the root causes of it. Monetary policy must not be ignored.

Accordingly, Turner's proposals are worthy of discussion, and I focus on two main types of measures: for the stability of financial markets and for economic stimulus.

In addition to the new financial market regulations already implemented, he wants three new additions: restrictions on the creation of fiat money, measures to make lending more expensive through taxation, and the development of hybrid bonds, especially related to mortgages, whose risk profile is identical to that of equity. Overall, the aim of this would be to make debt creation more expensive. These are points that deserve consideration, particularly since they would, for instance, equalize the tax advantages enjoyed by debt compared to equity.

However, he is primarily concerned with the financing of government programs to stimulate the economy with helicopter money, that is to say, the direct printing of central bank money without this leading to additional public debt. According to his view, perpetual stimulus programs could be financed this way. Although Turner sees the risk that printing money could lead to unacceptably high inflation, he appears to believe that the positive effects would dominate as long as only small amounts of helicopter money are distributed (Turner 2015 , p. 219). But how would letting this genie really out of the bottle affect confidence in monetary stability and inflation expectations? Is it likely that inflation expectations would remain unaffected, or, ideally, move within a desirable range to monetary stability? His solution also omits the question of the independence of central banks. How credible can a central bank be if it first mutated from its original price stability function as a lender of last resort - to a buyer of government bonds, as a buyer of last resort, only to assume now the mantle of a revamped fiscal policy as the spender of last resort? Although Turner argues in another publication that the central bank retains its autonomy by deciding on the extent of direct stimuli to the economy (Turner 2013), his line of reasoning appears to be more like circular logic. How independent can a central bank be if it undertakes tasks that are first and foremost the responsibility of fiscal policymakers because the latter are not able to or do not want to increase their deficits and debts themselves? Turner only refers to the Mephistophelian element in this policy - which the book's title already alludes to - to go even further beyond his previous writings and demands. In his previous essays, he postulated that purchasing government bonds and removing them from circulation should remain a one-time event to reduce debt. Furthermore, he argued that credible restrictions must be attached to avoid creating wrong incentives for the political class and to prevent the reoccurrence of such situations. In the case of direct financing of economic stimulus packages, as discussed here, this demand tacitly fades into the background because Turner recommends using helicopter money to fund government budgets constantly. He is not alone with this proposal. In a speech before the Japan Society of Monetary Economics in 2003 (Bernanke 2003), Ben Bernanke had already laid the blueprint for it by using the phrase "helicopter money" and referring to an expression - just as Turner did - originally coined by a young Milton Friedman (Friedman 1948). More recent offshoots of this proposal can be found from Willem $\mathrm{H}$. Buiter, who makes use of the example of the printing press to explain the end of deflation (Buiter 2014). Forays in the direction of spending programs financed by monetary policy to stimulate the economy constitute only one aspect in a more complex debate. They must be seen within the context of considerations about monetizing existing government debt itself, which is forming under the heading Modern Monetary Theory (Tymoigne 2014). The genie is out of the bottle. What is missing now is a debate about the risks and side effects of these political approaches. 


\section{References}

[1] Bernanke B., Some thoughts on monetary policy in Japan: Remarks by Governor Ben S. Bernanke before the Japan Society of Monetary Economics; 2003. URL: http://www.federalreserve.gov/ BOARDDOCS/SPEECHES/2003/20030531/ default.htm (abgerufen am 18.11.2015).

[2] Buiter W.H., The simple analytics of helicopter money: why it works - always, economics Discussion Papers, No. 2014-24, Kiel Institute for the World Economy, 2014.

[3] Friedman M., A monetary and fiscal framework for economic stability, American Economic Review, 38, 245-264, 1948.

[4] Naumer H.-J., Fördern Geldpolitik und Niedrigzinsen einen nachhaltigen Rückgang der Staatsschulden? Wirtschaftsdienst, 9. Jg., S. 614-618, 2015.

[5] Turner A., Debt, money, and mephistopheles: how do we get out of this mess? 2013. URL: http:// www.modernmoneynetwork.org/?q=content/debtmoney-and-mephistopheles-how-do-we-get-outmess (abgerufen am 18.11.2015).

[6] Turner A., Between debt and the devil - money, credit and fixing global finance, Princeton University Press, Princeton, 2015.

[7] Tymoigne É., Modern money theory and interrelations between the treasury and the central bank, Working Paper, No. 788, 2014. 
